\title{
Cree Elders' Perspectives on Land-Based Education: A Case Study
}

\section{John Hansen}

University of Saskatchewan

\begin{abstract}
This study deals with the notion that Indigenous peoples are concerned with preserving their communities, nations, cultural values, and educational traditions. Indigenous peoples have a landbased education system that emerges out of their own worldviews and perspectives, which need to be applied to research concerning Indigenous cultures. This work explores Indigenous land-based education through the perspectives of Cree Elders of Northern, Manitoba. Six Cree Elders were interviewed to explore the ideas and practices of land-based education. The article engages discussion of Indigenous land-based education stemming from Elders' teachings of Indigenous knowledge, cultural values, identity, and vision. Informed by Cree Elders, this qualitative study articulates an Indigenous interpretation of land-based education. Research findings demonstrate that Indigenous land-based education can be used to promote well-being among Indigenous peoples in Canada. While the study is based on the Cree experience in Northern Manitoba, its message is significant to many other Indigenous and non-Indigenous communities. Drawing on the Elders' teachings, policy recommendations are generated for advancing Indigenous landbased education
\end{abstract}

Keywords: Land-Based Education, Indigenous Knowledge, Culture, Healing, Decolonization

John G Hansen PhD, is an Associate Professor in the Sociology Department at the University of Saskatchewan. His research and teaching focus are in the fields of Indigenous Justice; Crime and Society, and Indigenous knowledge. He is a member of the Opaskwayak Cree Nation and now lives in Saskatoon, Saskatchewan and writes research on Indigenous topics.

Email: john.hansen@usask.ca 
Many contemporary theories, national and international policies do not incorporate Indigenous voices into their understanding of nation, or peoples. Such viewpoints reduce Indigenous peoples to citizens, ethnic groups, racial groups, or interest groups, which do not give accurate representation of who Indigenous peoples are. (Champagne, 2015, p. iv) Champagne (2015) argues that Indigenous voices are often treated as marginal within contemporary academic theories and institutional policies. Because Indigenous voices are marginalized, this study sought to promote Indigenous voices in the literature. Since colonized Indigenous peoples have been deterred from voicing their concerns and practising their own culture and land-based education traditions, it is understandable that there is a knowledge gap. It is conceivable, therefore, that a comprehensive discourse on how Omushkegowuk (Swampy Cree) Elders see and understand land-based education is not completely developed in the literature. This article provides a Cree model of land-based education that outlines the ideas and practices, which is lacking in the literature. However, this study developed out of the need to examine Elders teachings and thereby provides an understanding of how land based education occurred. This research hopes to provide a land based education model, model which have been used by the Swampy Cree-People of the Muskeg — of Northern Manitoba.

The Indigenous Elders in this study are members of the Cree Nation who, like many other Indigenous nations, have been colonized, dispossessed from their lands, and silenced (Adams, 1975; Champagne, 2015; Radu, House, \& Pashagumskum, 2014). The primary purpose of this study is to engage discussion about Cree Elders' voices and perspectives on land-based education. In conventional education, Indigenous voices are often marginalized and viewed as being unimportant or academically irrelevant (Champagne 2015; Hansen \& Antsanen, 2016; Truth and Reconciliation Commission of Canada [TRCC], 2015). The hypothesis of this discussion is that Indigenous peoples such as the Cree of Northern Manitoba are part of Canadian society, and will continue to be part of the social and cultural fabric of Canada for generations to come. Therefore, it is important to restore and develop land-based education in an Indigenous context.

Land-based education has taught people lessons for living for thousands of years-ways of life that today can be reclaimed and redeveloped through a decolonization process. The development of an Indigenous-based model of education that takes into account the needs, values, teachings, and cultures of Indigenous community members and nations is both a challenging and worthy endeavour. The challenge rests in the fact that Indigenous-based models of education require more from the learner than simply studying culture from textbooks. For instance, Indigenous students ought to have contact with Elders, relatives, and knowledge keepers who can pass down knowledge and culture. An Indigenous-based model of education would help students develop solid community commitments, and to foster knowledge of their culture and identity in ways that prepare them to be knowledgeable in their own culture and traditions, all the while being fully prepared to function in Western culture and society.

This article provides considerable discussion on Cree Elders' perspectives of the land, culture, and experience. The article also briefly discusses Western interpretations of Indigenous education that creates the need to decolonize and develop land-based education (Adams, 1975; Brown, 2004; Champagne, 2015; Wildcat, McDonald, Irlbacher-Fox, \& Coulthard, 2014). In a Western-based education system, Elders and cultural knowledge do not have a primary role in educating students and consequently students do not gain an understanding of the land and its significance in Indigenous cultures. Decolonization therefore seeks to decentre Western interpretations of Indigenous education that often do not teach the values, culture, and language of Indigenous people. 
This article can be considered a decolonization project. Linda Smith (1999) notes that "decolonization is about centering our concerns and worldviews and then coming to know and understand theory from our own perspectives and for our own purposes" (p. 39). Smith reveals that Indigenous perspectives and worldviews are paramount in a decolonization project, and I hope that the significance of Cree Elders' perspectives on land-based education will be reflected in this paper.

Because Elders are guides in many Indigenous communities, the author interviewed six Cree Elders as participants in this study to explore the notions of Indigenous land-based education. The study is qualitative in nature and uses ethnographic open-ended interviewing methods, field notes, audio-taped conversations, and observations (Creswell, 1998). The study's research methodology is based on Creswell's (1998) assertion that qualitative research is appropriate when the central research question(s) ask "how" (p. 17), in this case: (a) how Indigenous land-based education within Cree culture is interpreted, and (b) how six Cree elders understand land-based education. The nature of these questions suggests this inquiry is suitable for a qualitative examination. Creswell (1998) notes that a qualitative inquiry entails that "the researcher builds a complex, holistic picture, analyzes words, reports detailed views of informants, and conducts the study in a natural setting" (p. 15).

\section{Literature Review}

While this study deals primarily with Indigenous Cree teachings in Northern Manitoba, Canada, the ideas relating to Indigenous land education apply to many other Indigenous peoples in Western countries. The article encompasses and Indigenous perspective corresponding to the negative impacts of colonization on Indigenous communities, Cree cultural understandings of land-based education, and spiritual teachings that shape a deep respect for the land. The interviews conducted with Cree Elders as primary sources also are reflected in the literature. For example, Radu, House, and Pashagumskum's (2014) influential article "Land, Life, and Knowledge in Chisasibi: Intergenerational Healing in the Bush composes (offers) a Cree account of a matter between the Cree and the federal government in which the former were removed from their traditional territory. However, the land continues to be a non-toxic space where traditions and healing still manifest. As Radu et al. (2014) report:

In 1980, the Fort George iiyiyiwich were unceremoniously moved across the James Bay to the present-day community of Chisasibi-a place not of their choosing. The impacts of a cumulative range of stressors, from residential school abuses, mercury poisoning, and land loss from hydroelectric development, as well as overt paternalism from both governments and settlers working within Cree institutions, have disrupted family structures and undermined individual and community wellbeing. Nevertheless, the land, as much as it has endured, still offers a place and space where relationships of respect and love can be rebuilt and strengthened. (p. 86)

The above passage illustrates how the Cree use the land in ways for subsistence: hunting, fishing, living, and healing. Thus, Indigenous communities tend to perceive and understand the land in ways that are spiritual and healing in nature. Many Indigenous Elders teach us that the Creator provided the people with particular land to live on and sustain. Indigenous peoples demonstrated appreciation to the Creator through ceremonies, and by showing respect to plants, animals, and the land that enables them to live. Still, they did not consider themselves owners of the land; they used 
the land in ways that ensured it would be sustained for future generations (Castellano, 2000; Champagne, 2015; Ermine, 1995; Hansen, 2009; Wotherspoon \& Hansen, 2013).

Indigenous peoples also have a shared colonial experience of being dispossessed from the land (Adams, 2000; Blaut, 1993; Champagne, 2015; Charlton \& Hansen, 2017; Hansen \& Hetzel, 2018; Hansen, 2012; Hansen, 2015a; Hansen, 2015b; TRCC, 2015; Wildcat et al., 2014). Wildcat et al. (2014) suggest that "if colonization is fundamentally about dispossessing Indigenous peoples from land, decolonization must involve forms of education that reconnect Indigenous peoples to land and the social relations, knowledges and languages that arise from the land" (p. 1). It is well documented that Indigenous peoples in Canada experienced the colonization of their lands, forced assimilation, residential schooling, and the suppression of their languages, spiritual practices, identity, and culture (Adams, 2000; Antsanen \& Hansen, 2012; Blaut, 1993; Champagne, 2015; Charlton \& Hansen, 2016; Ermine, 1995; Hansen \& Antsanen, 2016; Hansen \& Antsanen, 2012; Diangelo \& Sensoy, 2012; TRCC, 2015).

Although Indigenous peoples have experienced colonization and suppression of their cultures, land-based education ideas and practices still exist within many Indigenous communities. In contemporary Indigenous communities, there are Elders who continue to teach the succeeding generations to have respect for the land, plants, animals, and water. According to the Indigenous sociologist Duane Champagne (2015), the "land was a means for life and livelihood, and the people were guests of the Creator" (p. 4). As Champagne (2015) notes,

The land was given to the people by the Creator, who had a sacred task or purpose for the people. The people gave thanks to the Creator through ceremonies, and by showing respect to the land, plants, animals and other beings living on the land. Indian people were not owners of the land, and shared the land with other power beings with whom they had to show respect. (p. 4)

These kinds of understandings demonstrate the spiritual nature of Indigenous worldviews and perspectives, which have been an important factor in the development of land-based education (Adams, 1975; Antsanen \& Hansen, 2012; Castellano, 2000; Ermine, 1995; Hansen, 2013; TRCC, 2015; Wotherspoon \& Hansen, 2013).

\section{Misinterpretations of Indigenous Education}

In many ways, there have been problems with Western interpretations of what constitutes Indigenous education. As Champagne (2015) observes:

About two and half centuries ago, northeastern Indian leaders chided American colonial educators for wasting their young men in European education. The young men who attended colonial schools returned with no skills to hunt, could not run, could not take care of themselves in the wilderness, did not fit into tribal communities, and tended to break down into depression and drink. (p. 48)

Often, the educational approach has persisted in trying to change Indigenous people into Western people. According to Wildcat et al. (2014), "Settler-colonialism has functioned, in part, by deploying institutions of western education to undermine Indigenous intellectual development through cultural assimilation and the violent separation of Indigenous peoples from our sources of knowledge and strength - the land" (p. 3). In other words, colonial Indigenous education has been geared towards assimilation into Western culture rather than towards maintaining Indigenous culture and identity. As a result, Indigenous learners have long been perceived as a "problem" in 
conventional schools. Adams (1975) maintains that colonial education marginalizes Indigenous learners and destroys their self-esteem:

The school systematically and meticulously conditions natives to a state of inferiorization and colonization. It does this in a number of ways: most important, however, is that it teaches the languages, literature, and history of the colonizer and thus forces the students to deny their language, culture, and essential being. (p. 152)

Adams clearly illustrates the tendency of education in Canada to emphasize Western understandings of education. Adams (1975) also states that Indigenous students are socialized to assimilate into the underclass of the society: "Schooling leads to alienation, subordination, and conformity. Instead of providing social mobility and serving as an equalizer for its citizens, it rigidly maintains the class system" (p. 159). Therefore, the dominant groups' language, history, and culture are emphasized while Indigenous language and culture are marginalized.

\section{Decolonizing Indigenous Education: A Land-Based Approach}

Times of course change, and today educational discourse now recognizes that Indigenous education should convey Indigenous ways of knowing and being, and so there is much interest in decolonizing Indigenous education. However, any model of decolonizing Indigenous land-based education should have a vision and objective for the future well-being of Indigenous communities. In its research with Indigenous Elders, the TRCC (2015) reports that there is much work to be done in terms of developing the future well-being of Indigenous communities and promoting the reconciliation of relationships:

We have work to do. That work we are [already] doing as [Aboriginal] peoples. Our relatives who have come from across the water [non-Aboriginal people], you still have work to do on your road. ... The land is made up of the dust of our ancestors' bones. And so to reconcile with this land and everything that has happened, there is much work to be done ... in order to create balance. (Elder Mary Deleary, as cited in TRCC, 2015, p. 9)

Elder Mary Deleary suggests that the land is significant to fostering improved relationships and reconciliation for both Indigenous and non-Indigenous Canadians. However, in order to do so, one must examine the traditional teachings that demonstrate respect for the land.

Many critics recognize the significance of Indigenous teachings in relation to the development of Indigenous community well-being and healing (Champagne, 2015; Hansen \& Antsanen, 2017; Radu et al., 2014. For instance, Hansen and Antsanen (2017) observe that "Indigenous lives and communities can be improved by connecting to traditional teachings, practices and spiritual ceremonies" (p. 16). Smith (1999) reminds us that Indigenous education involves a decolonizing movement that seeks to restore the cultural ideas and practices from a history of colonial oppression, and that "cultural survival, self-determination, healing, restoration and social justice are engaging Indigenous researchers and Indigenous communities in a diverse array of projects" (p. 142). Indigenous land-based education thus is a fundamental part of decolonization because it promotes an Indigenous model of education in a culturally appropriate way; it is more than a set of beliefs.

Indigenous land-based education has developed into a finely tuned model of Indigenous ways of knowing (Ermine, 1995; Hansen \& Antsanen, 2016). Chandler and Lalonde (1998) have found that restoring the teachings within Indigenous education has produced some incredible results in Indigenous communities, and that those which "have taken active steps to preserve and rehabilitate their own cultures are shown to be those in which youth suicide rates are dramatically lower" (p. 
191). Brendtro, Brokenleg, and Van Bockern (1998) share a similar perspective and claim that atrisk youth can benefit from being exposed to holistic, traditional Indigenous teachings. Brendtro et al. (1998) further note that

The number four has sacred meaning to Native people who see the person as standing in a circle surrounded by the four directions. ...We believe the philosophy embodied in this circle of courage is not only a cultural belonging to Native peoples, but a cultural birthright for all the world's children. (p. 45)

This passage suggests that Indigenous teachings are relevant to the world and that these teachings can benefit all humanity.

Brown (2004) notes that Western philosophy is not very holistic because it tends to suppress the emotional realm, and that such a lack of emotional development has had some negative impacts on Indigenous peoples:

when the European male (Zeno, Plato, Socrates, Aristotle, Descartes, etc.) separated their mind from their heart ... this emotional detachment from their lands allowed them to leave their homeland and export their philosophy of oppression throughout the globe. When Europeans became detached from their affective awareness, it allowed them to avoid the emotional feedback from their exploitation of the world's peoples and environments. The oppression of the European heart by the European mind was the beginning of the oppression of Indigenous peoples, women, and the earth itself. (p. 28)

For Brown, such lack of emotional development has been an important factor in the ensuing exploitation of the land. Similarly, Hart (2002) claims that Eurocentric colonizers espoused two basic views to justify the exploitation of Indigenous lands:

First, they hold a self-righteous stance that their views and actions are the proper and best ones to be held by all peoples of the world. In turn, Aboriginal people's worldviews are trivialized, our histories are rewritten from the eyes of the colonizers, and our values are demeaned and manipulated. The second reason lies with the colonizers' need to legitimize their dominion over Aboriginal peoples' land. If the Aboriginal peoples' cultures keep them tied to the land, then this connection needs to be severed so that the colonizers' claim over the land and its resources can be confirmed. (p. 25)

This passage by Hart, demonstrates the notions of so-called European superiority and Indigenous inferiority that have dominated society for so long. Such views of Indigenous peoples' inferiority were a major stimulus towards suppressing Indigenous culture, values, and philosophical thought.

\section{Protection of the Land}

Although Indigenous peoples such as the Cree have been colonized, they nonetheless have maintained their cultural teachings that advocate protection of the land, which is reflected in the "Idle No More" movement. Wotherspoon and Hansen (2013) observe that Idle No More is based on ancient Indigenous cultural teachings that promote respect for the land and embrace "a vision to protect the land and water that leads to sustaining rather than exploiting the environment" ( $\mathrm{p}$. 27). Wotherspoon and Hansen (2013) add that

Although the Idle No More movement seems to have disappeared from the media, it is in fact very much alive and vital in and beyond Indigenous communities. Idle No More has not disappeared but has demonstrated its deep roots as part of an established system of cultural teachings and values that advocate respect for the environment that has been continuously reproduced to the present time. Idle No more speaks of modern Indigenous 
interpretations of development that are rooted in the ideology of future wellbeing of succeeding generations. (p. 33)

Indigenous peoples, communities, and nations are concerned with protecting and preserving the environment and their cultural values and understandings. Indigenous peoples are also concerned with reproducing cultural teachings. As Hansen and Antsanen (2016) note, the Elders "still teach us that the land should not be sold or destroyed" (p. 3). Thus, Indigenous land-based education has functioned to socialize community members into Indigenous society and to respect the land.

In spite of the above, Western school systems have failed to develop Indigenous students' potential because of generations of colonial approaches to education. Simply put, many Indigenous students are not taught about collective Indigenous values and teachings. In conventional education, Elders often play a marginal role in the teaching of Indigenous students. Consequently, many Indigenous students do not develop their educational potential and do not identify with either Indigenous culture or mainstream culture. The Elders suggest that land-based education has the potential to develop students in ways that promote their individual and community well-being.

\section{Research Methods Including the Voices and Knowledge of the Elders}

Indigenous voices are unheard and often considered to be unimportant and/or academically irrelevant within scholarly research (Champagne, 2015; Smith, 1999; Wotherspoon \& Hansen, 2013). This study argues that Elders have been the customary guides and teachers in Indigenous societies for thousands of years, and are still regarded highly in many Indigenous communities at the present time.

As an insider of the group examined in this study and a member of the Opaskwayak Cree Nation, I grew up in Northern Manitoba, Swampy Cree territory, and I have observed the traditional value of respect that the Cree have for the old people. It is the Elders who carry the traditional knowledge, and it is this source that I wanted to focus on in this research. The Elders are appreciated for their experience and knowledge of the community-its history, morals, customs, and ceremonies. The Elders play significant teaching roles in many Indigenous communities, whether they are widely known or not. I turned to my Elders for knowledge and guidance as is the custom of the Cree. I knew the Elders before I conducted this study, and I recognize them as my Elders because I have observed their personal character, wisdom, and knowledge of Cree culture. This form of Indigenous research methodology is similarly reflected in the works of Indigenous scholarship (Brown, 2004; Hansen, 2013; Hansen, Booker, \& Charlton, 2014; Hart, 2002).

\section{Participants}

The Elders were recruited from the Opaskwayak Cree Nation territory by the researcher, who approached them and explained the nature of the study. Since the Elders knew and trusted me, they were happy to participate. Opaskwayak Cree Nation is a Swampy Cree (Omushkegowuk) First Nation community located in Northern Manitoba (about 600 kilometers northwest of Winnipeg), situated at the junction of the Saskatchewan and Pasquia rivers. Opaskwayak Cree Nation has a total population of 5,368 (Statistics Canada, 2016). The Cree word Opaskwayak means "narrows between woods."

To demonstrate respect for the Elders and honour Indigenous ethics, culturally sensitive protocols were followed. This included offering cloth, tobacco, and sweet-grass to demonstrate 
respect and acknowledge the Elders' contributions to the study. The researcher used the tools of ethnography: open-ended interviewing methods, field notes, and audio-taped conversations. During my interviews with the Elders, I observed their descriptions of land-based education. The Elders taught me much about the traditional teachings and how they perceive and understand the land. I had the privilege of having in-depth conversations with the Elders on topics about environmental concerns, spirituality, and how personal development was promoted through a spiritual connection to the land. For example, Elder Stella describes her personal development in the following way:

My personal development was given to me in a very deep sense as I was growing up because it was connected with my spirituality. And it was the stories that were told that developed us into who we are because when you think of these stories that were told there is so much about me that I know is spiritual.

The more Cree teachings are examined, the more they are seen as spiritual. Indigenous teachings are powerful because they become an integral part of the thought processes of the Indigenous people in their communities and shape their reality and identity.

The particular interpretation of Indigenous Elders depends also upon their particular experiences. For example, Elder William Lathlin infers that there has to be a spiritual connection to the land for communities to function:

There has to be that connection because if there isn't, to me, then it's all hostile; there is no peace. If you go out into the bush by yourself it is so peaceful, and you can hear the bugs on the floor or on the grass and the trees.

Specific understandings, and nuances of Cree customs, spirituality and traditional teachings were observed in my visits with the Elders, which include significant meanings, values, and perspectives that are found the Cree community. As Woods (1996) notes, "ethnography is concerned with what people have, how they behave, how they interact. ... It aims to uncover beliefs, values, perspectives, motivations" (p. 4). The interviews were tape recorded with permission and were conducted in the traditional Omushkegowuk (Swampy Cree) territory of Northern Manitoba. Each Elder was interviewed for approximately 90 minutes and all interviews were conducted during the winter season, which in the Cree culture tends to be a time for sharing stories (Hansen, 2013). All the Elders with one exception are named: Jack is the pseudonym for one participant who chose to remain anonymous, and the pseudonym is used to refer to him throughout this paper.

Another participant was Sylvia Hansen, who is a member of the Opaskwayak Cree Nation. She was born in 1937 and experienced life on Opaskwayak territory; however, like many other Indigenous children of her time, she was forced to attend residential school. Sylvia is fluent in the Cree language. Stella Neff is a member of the Misipawistik Cree Nation or Grand Rapids First Nation, and is fluent in the Cree language. William G. Lathlin is a member and former chief of the Opaskwayak Cree Nation, and fluent in Cree language. John Martin is a member of the Mosakahiken Cree Nation or Moose Lake reserve and is fluent in Cree language. Dennis Thorne, an Elder of mixed Indigenous ancestry (primarily of Cree descent but including also Dakota and Ojibwa) was born in 1939 in Wanless, Manitoba, a small Métis community located some 50 kilometers north of Opaskwayak Cree Nation.

The Elders were interviewed in accordance with Creswell's (1998) work on qualitative research. As such, the interviews were conducted at a time, place, and setting chosen by the Elders. As Burgess (1984) advises, the open-ended questioning style provides the participants "an opportunity to develop their answers outside a structured format" (p. 102). These open-ended interviews are also culturally appropriate in the Indigenous community, particularly when 
interviewing Elders. I transcribed the interviews myself in order to develop a better understanding of the data and to identify common themes to draw conclusions. This process enabled me to identify common themes in the findings.

\section{Analysis of Themes}

Stake (1995) notes that "there is no particular moment when data analysis begins. Analysis is a matter of giving meaning to first impressions as well as to final compilations" (p. 71). My analysis began from the moment I began interviewing the Elders. To ensure that I characterized the Elders in context, I recorded the interviews and consulted with the Elders to confirm that my interpretation of the transcripts reflected what the Elders meant.

During the analysis, I searched for themes in relation to the Elders' teachings of land-based education. I reflected on the data, and the themes that emerged are identified as follows: counseling from the Elders, traditional teachings, ceremonies, and a connection to the land. The themes revealed that obstructions to well-being were disconnection from the land, colonization, and misuse of medicine. According to most participants, the disconnection from the land weakens the potential for well-being. A key way Western colonial powers weakened Indigenous nations was to disconnect Indigenous peoples from the land (Adams, 1975; Antsanen \& Hansen, 2012; Hart, 2002; TRCC, 2015; Wildcat et al., 2014). Hart (2002) notes that "If the Aboriginal peoples' cultures keep them tied to the land, then this connection needs to be severed so that the colonizers' claim over the land and its resources can be confirmed" (p. 25). The Elders perceived that the disconnection from the land decreases the capacity for individual and community well-being, and that colonialism functions to disconnect Indigenous peoples from the land. The Elders expressed that land-based education involves re-connecting to the land, traditional teachings, practices, and ceremonies; it involves returning to cultural practices and healing ceremonies that were suppressed through colonization. According to the Elders, the significant obstructions to well-being arose from the alienation of Indigenous language, traditional teachings, and values that emerged out of colonization. However, the major obstruction is the disconnection from the land, which is crucial to Indigenous identity and culture. Elder Stella Neff, for example, describes how the community was impacted by the Indian residential school system, which has become recognized as a part of Canada's colonial history:

When the residential schools took the children away, that had an impact on our people in Grand Rapids and so when that happened and all those things combined it was a disaster for the roles of women and men because when they lost their children. That's when they started fighting and the angry aggression was a disaster for our community.

Stella's statement clearly illustrates the negative impacts of residential schools. Stella also shared later that she misses the respect for the land:

We were taught gently; we didn't get the stick like what was introduced, or like a strap like we got in school. It was by a gentle teaching and these values were passed on like respect and love for land and honesty and good behaviour. So the values were priceless for me and I'm so sorry that the system is gone.

The land-based education Stella received was comprised of gentle teachings and stories that taught the people to have a love for the land. When the Indigenous education system had been overthrown by colonial education, Stella felt a deep sorrow.

Elder William Lathlin describes the impacts of the residential schools in a similar way: 
The impact of it has split up families, took away the children, and so some of the parents didn't really know the rules anymore. Because the state more or less invaded the home, it affected how the parents raise the child, and the responsibilities of how to raise the child and the consequences of their action or inaction. So those things changed.

The residential schools have become a recognized part of Canada's unfortunate colonial history; however, the inclusion of Indigenous perspectives in Canada's history is a positive step towards healing from colonialism and restoring and redeveloping Indigenous land-based education.

\section{Discussion of Findings}

\section{Summarizing the Elders' Discussions}

Participants' narratives about land-based education demonstrate that the Cree Elders have a spiritual connection to the land. The narratives have been perpetuated over many generations, and demonstrate how teaching is done in the Cree world. The participants described the traditional educational process as being holistic, which makes spirituality significant. The Elders expressed that the purpose of traditional education emphasized the significance of respecting the land and the reproduction of culture, ceremonies, and traditional thought. This dimension of the land became increasingly apparent in the participants' discussion, which adheres to a belief in Manitou, or the Great Mystery, which the Cree call Kitche Manitou. The mystery also corresponds to one's personal "soul" or the inner self, which also relates to how the individual is connected to all creation.

\section{A Spiritual Connection to the Land}

Traditionally, Indigenous Elders guided the community and the educational process. Today, Elders continue to contribute their knowledge to education. The Elders discussed a spiritual connection to the land. For example, John shared that

Everything is spiritual: the trees are alive, the grass, the rocks, they have a spirit. The animals, they have a spirit and so the ceremonies are based on those teachings, like the things that we do, it was for a purpose; ... the purpose is spiritual. We didn't use the bible, so we used the feather, because that feather teaches us; or the rock, it affects every one of us and it is spiritual. These are the kinds of things that helped the Cree people, and I hope that they continue. ... We have to use the spiritual part, the spiritual side, when we do our work and in the conflict resolution and in peace that's what we're asking for. If you understand the wind [makes a circular movement with his hands] to blow the bad things away, to blow in the good things into your mind-when you're doing that, that's what the Elders do; one of the grandfathers will help you with that process.

John provides an interesting discussion on the spiritual connection to the land. In terms of his own understanding, John would like to see these traditional teachings continue and suggests that the "spirit" or the "soul" is what connects us all. John suggests that we need to realize such interconnectedness - that each action has an impact on all things. For John, the land is crucial for teaching important lessons and appropriate behaviour; he notes that everything is alive-the animals, the plants, the rocks - and they have a spirit. 
William responded to the same question by stating that:

When you go into these ceremonies like the sweat lodge and you sweat you feel nice and clean. In your mind after you've been through that in your meditating, your mind is receptive and you're ready for suggestions by the Elders.

William's statement speaks of the significance of keeping an open mind when being taught. He also refers to the sweat lodge as a cleansing process that contributes to receiving teachings from Elders. Similarly, Stella states that:

Spirituality is the essence of the being, the being that comes from your environment. My grandfather would always take us to this place where poplars are in a circle. And he would take us there and it was on the swiftest part of the rapids that he would stop and he would have a hard time stopping there because it was swift and he would grab a branch because the water was so swift and he would stop there every time we went on the rapids and we would walk up to this place and I never saw anything there in particular. I couldn't tell you if it was wonderful because I never saw it. I could tell you it was a clearing and when we walked up to it my grandfather said Manitou, which means God is here and everybody quit talking. ... When we walked under this clearing we got this amazing sense. I could never describe it because you have to believe what this sense was; it was a feeling that there was a presence there but you have to experience it and you can't describe how it feels.

This passage demonstrates the belief in a Great Mystery or a spirit. For the Cree, the Great Mystery is Manitou and there is energy or a spirit in all of us; in fact, there is energy or a spirit in all of creation, which indicates that spirituality and ceremony are important to the education process.

\section{Personal Development}

The Elders spoke of how personal development is related to teachings related to ceremonies. Stella, for instance, said:

My personal development was given to me in a very deep sense as I was growing up because it was connected with my spirituality. And it was the stories that were told that developed us into who we are because when you think of these stories that were told there is so much about me that I know is spiritual. And here it was from the teachings and yet although they never mention ceremonies I know it and yet I knew when they mention sweat lodge I knew it was something that was special; I knew when I heard that first drum, I knew I remembered something from the back of my mind from way before and I got the sense that, yes I know this sound. I heard the sound because when it's a part of you for millennia you have to recognize it when it's in your blood; you have to recognize it.

Stella stresses the importance of teaching traditional stories and demonstrates the notion that a collective memory of the people is transmitted through the bloodline. In his discussion of personal development, John speaks of the significance of the process:

When you're going to do fasting, you never say that "I'm going to fast for 4 days." But if you can go for 4 days that's good, and if you can go for 2 days that's good, and if you can only go for 1 day that's good too. Like me, I started fasting at my place and then I went to finish off in the mountains. I went to the mountains and I started outside of my house. When you fast, you have to make yourself a lodge or something that you can [pause] ... well you know sometimes it rains, and we don't want you to suffer in the rain and get cold so this is why we build ourselves a lodge. 
John refers to knowing one's limitations and abilities. In the context of fasting, individuals can learn to develop their abilities. Personal development, then, is a process of learning and introspection; as John noted, "I started fasting at my place and then I went to finish off in the mountains." Thus, in pursuit of personal development, John describes a process of introspection and a connection to the land. The fasting is done on the land, in nature.

In addition, it is interesting to observe the spirituality and the stories that speak of healing from sickness, such as those shared in Sylvia's discussion:

Well, one time my mother just about died and that's why we went to Cedar Lake. Because there was this old man and he was from Cedar Lake, and he told us of an old lady that cured people. I was just a little girl at that time. And my mother took a bottle of wine and I think she gave her 10 dollars. And that old lady was singing a song and she was dancing around. Then she took a pillow, and put the pillow on her knees, and she told my mother to lay down, and she put her hand on her ear and turned it back and then she showed her and said see it is right here. And there was a worm there with those white berries, those red willow trees, I think they're called, and there was one of those with the worm. She took it out of her, and she said, "do you want me to send this back or do you want me to burn it?" And my mother said to burn it, so she burned it and that was it.

Sylvia's statement reveals an aspect of the Cree spirituality in accordance with a belief in spiritual healing. In this case, when Western medicine failed to heal, the grandmother was healed through Cree spirituality. Within such a spiritual dimension, it is recognized that sickness does not occur strictly by violation of sacred or tribal laws; it happens, however, that sickness can be caused by those who use medicine to hurt rather than to heal. Altogether, the story about how the grandmother almost died demonstrates the accounts in which Indigenous peoples experience healing. Healing took place by strengthening the body's natural defenses and by applying medicinal plants that are known through Indigenous land-based education.

Indigenous people such as the Cree understood and valued the land because the land not only was used for teaching values for life but was also necessary to sustain life itself. Therefore, it follows the Indigenous tendency to protect the land using three lenses, as discussed by Stella. The first lens emphasizes how dependency on the land instills an awareness of the need to value and preserve the land. The second lens recognizes that humans are responsible for guarding against wrongdoing that can negatively impact on the land (such as through fire). Lastly the third lens described by Stella points to the land itself, as a tool that teaches and corrects behaviours, particularly through spiritual visions. As Stella explains:

When you're so dependent on the land like we were, then the land had to be a part of every decision because that's what sustained us, so protecting the land and protecting the hunting areas, the trapping areas, and all of the water areas, it had to be above all protected from any damage. So I think that if there was any conflict in these areas it was considered very serious, especially if there was any kind of environmental damage done by the wrongdoer. I am specifically thinking about setting fire or things like that, which could destroy so much land. ... Sometimes they talk about it where they are just as some people on an island. My brother went there for 3 or 4 days on an island because he was drinking too much and so my father just dropped them off there. So that was something he could think about for a few days later but he never forgot that experience, he never forgets 
it because he saw himself there when you start getting hungry and when you start seeing visions and when he start seeing himself he became scared and so that's one lesson we used: to go and see visions.

Stella's narrative conveys explicit connections to the land as a deep reflective and spiritual space for teaching and learning. One important aspect to understand in Stella's answer is the concept of understanding life as a result of being isolated and connecting to nature. In this case, Stella's brother is dropped off on an island, which is another way of connecting to the land. The traditional spiritual connection to the land is reflected in the quest for visions that help individuals find their purpose in life.

In his response to the same question, William stresses the connection to the land and peacemaking methods:

There has to be that connection because if there isn't, to me, then it's all hostile; there is no peace. If you go out into the bush by yourself it is so peaceful, and you can hear the bugs on the floor or on the grass and the trees.

William's response emphasizes the importance of the land and the traditional way of life upon which our society was structured. It appears that when William speaks of the peace and silence when out on the land, one must realize that this insight is consistent with John's statement that "the world is alive" and it also suggests that the land is alive and must be respected. Similarly, Dennis discussed the ways in which healing can occur in the sweat lodge:

The sweat lodge was used for purification to take out the negative. It took out the negative and put it away so you don't hurt anybody in order to get back to the positive outlook. If a person did something wrong, all the people in the sweat lodge got a scolding because that lesson was for all of us, not just for that individual.

Dennis explains that the sweat lodge is instrumental in restoring a positive outlook on the world. $\mathrm{He}$ also mentions that a lesson for one is a lesson for all, and is an indication that an individual's action affects the entire community.

Jack in turn discussed the spiritual aspect of traditional medicines as follows:

When I was a boy I cut my toe almost in half. There was an old woman who mixed some medicines together and she put it on my cut and after a few days my toe was better. But there was also talk of medicine men who some people believe held powers, that they could do things to you like twist your face or make you sick. But only if you believe in that are they able to have some control over you.

According to Jack, traditional medicine not only is used for healing but sometimes also is used inappropriately in order to hurt others. The point here, however, is that such misuse was perceived as inappropriate and accordingly the point about control is significant. Here, spirituality and medicine become interconnected. For the believer, spiritual medicine is real. In other words, Jack suggests that one's physical well-being is not only physical but also spiritual in nature. The Elders' teachings have been passed down for generations. These ancient teachings are holistic, and the spiritual accounts of medicine being used for healing as well as hurting are not fictions but rather are recognized as actual accounts within the Swampy Cree culture.

Now I will organize the themes that emerged in in the interviews with the Elders. The themes are identified in the tables below, which I describe in terms of factors that promote well-being and factors that obstruct well-being. 


\section{Identifying Significant Factors}

Table 1

Factors That Promote or Obstruct Well-Being

\begin{tabular}{|c|c|c|}
\hline Participant & Factors that promote well-being & Factors that obstruct well-being \\
\hline Stella Neff & $\begin{array}{l}\text { ceremonies; vision quest; connection } \\
\text { to the land; stories; counseling from } \\
\text { the old people }\end{array}$ & disconnection from the land \\
\hline Sylvia Hansen & $\begin{array}{l}\text { counseling from the old people; } \\
\text { spirituality; traditional medicine }\end{array}$ & misuse of medicine \\
\hline John Martin & $\begin{array}{l}\text { Language; spirituality; connection to } \\
\text { the land; ceremonies; sweat lodge; } \\
\text { healing circles; vision quest; the old } \\
\text { people }\end{array}$ & $\begin{array}{l}\text { mainstream justice system; } \\
\text { exclusion of spirituality in the } \\
\text { courts; exclusion of community } \\
\text { in the justice process }\end{array}$ \\
\hline William Lathlin & $\begin{array}{l}\text { the old people; connection to the } \\
\text { land; language; ceremonies }\end{array}$ & disconnection from the land \\
\hline Dennis Thorne & $\begin{array}{l}\text { counseling from the old people; } \\
\text { ceremonies; sweat lodge }\end{array}$ & erosion of traditional culture \\
\hline Jack & connection to the land; the old people & misuse of medicine \\
\hline
\end{tabular}

\section{Conclusions}

This article engaged in a discussion of Cree Elders' perspectives of land-based education in Northern Manitoba. The cultural ideas contained in the Elders' teachings demonstrate that landbased education is significant to Indigenous education. The Elders expressed a spiritual connection to the land, the desire to preserve their cultural values and the belief that land-based education is significant to Indigenous people's personal and community well-being. This study provides an example of an Indigenous interpretation of land-based education from the perspectives of Cree Elders. The study is important because a comprehensive understanding of Swampy Cree landbased education is addressed insufficiently in the literature. This article is worth reading by educators, researchers, and community members because Indigenous communities have been impacted by colonization.

An important impact of colonization has been the decrease in well-being in Indigenous communities. The evidence of a decrease in well-being is found in the array of studies documenting educational disparities between the Indigenous peoples and mainstream Canadians, as well as the disproportionate instances of incarceration, alcohol and drug abuse, and suicide among the former. However, research findings suggest that Indigenous land-based education is important to Cree Elders, individuals, and communities. Understood this way, the Cree Elders interviewed in this study recognize that land-based education predicated on cultural teachings can be used to promote well-being of the Opaskwayak Cree Nation.

While the study is based on the Cree experience in Northern Manitoba, its message is significant to many other Indigenous and non-Indigenous communities. Drawing on the Cree Elders' 
perspectives and teachings, the following recommendations are made to advance Indigenous education:

1. Educational institutions - universities, colleges, and both public and band-controlled schools alike, including Opaskwayak Cree Nation — should sustain and support Indigenous land-based education. More specifically, Indigenous Swampy Cree land-based education requires greater funding to provide successful educational outcomes.

2. Efforts should be made to increase knowledge devoted to raising awareness of Indigenous land-based education and cultural knowledge among non-Indigenous communities, who also could benefit from learning about Indigenous land-based education.

3. National and provincial government funding agencies should continue to support education and cultural programs that have demonstrated success in Indigenous communities. 


\section{References}

Adams, H. (1975). Prison of grass: Canada from the Native point of view. Toronto, ON: General Publishing.

Adams, H. (2000). Challenging Eurocentric history. Expressions in Canadian Native studies, 4053.

Antsanen, R., \& Hansen, J. G. (2012). Stories of culture and justice in the North. In S. Matheson \& J. Butler (Eds.), The fictional North: Ten discussions of stereotypes and icons above the 53rd parallel (pp. 7-16). Newcastle upon Tyne, UK: Cambridge Scholars.

Blaut, J. M. (1993). The colonizer's model of the world: Geographical diffusionism and Eurocentric history. New York, NY: The Guilford Press.

Brendtro, L., Brokenleg, M., \& Van Bockern, S. (1998). Reclaiming youth at risk: Our hope for the future. Bloomington, IN: Solution Tree.

Brown, F. L. (2004). Making the classroom a healthy place: The development of affective competency in Aboriginal pedagogy (Doctoral dissertation). University of British Columbia, Vancouver. Retrieved from https://open.library.ubc.ca/cIRcle/collections/ubctheses/831/items/1.0055621

Burgess, R. (1984). In the field: An introduction to field research. London, UK: Routledge.

Castellano, M. B. (2000). Updating Aboriginal traditions of knowledge. In G. J. S. Dei, B. L. Hall, \& D. G. Rosenberg (Eds.), Indigenous knowledges in global contexts: Multiple readings of our world (pp. 21-36). Vancouver, BC: UBC Press.

Champagne, D. (2015). Indigenous nations within modern nation states. Vernon, BC: JCharlton.

Chandler, M. J., \& Lalonde, C. (1998). Cultural continuity as a hedge against suicide in Canada's First Nations. Transcultural Psychiatry, 35(2), 191-219. doi: $10.1177 \% 2 F 136346159803500202$

Charlton, J., \& Hansen, J. G. (2016). Visualizing Indigenous perspectives of how the Saskatoon Community Youth Arts Program (SCYAP) addresses social exclusion. The Annual Review of Interdisciplinary Justice Research, 5, 394-421. Retrieved from https://www.cijs.ca/volume-5

Charlton, J. E., \& Hansen, J. G. (2017). How does Indigenous knowledge enhance alcohol and substance abuse recovery programs. The Quint, 9(4), 208-256.

Creswell, J. W. (1998). Qualitative inquiry and research design: Choosing among five traditions. Newbury Park, CA: Sage.

DiAngelo, R., \& Sensoy, O. (2012). Is everyone really equal? An introduction to key concepts in social justice education. Teachers College Press. 1234 Amsterdam Avenue, New York, NY.

Ermine, W. (1995). Aboriginal epistemology. In M. Battiste \& J. Barman (Eds.), First Nations education in Canada: The circle unfolds. Vancouver, BC: UBC Press.

Hansen, J. G. (2009). Cree restorative justice: From the ancient to the present. Kanata, ON: JCharlton.

Hansen, J. G. (2012). Countering imperial justice: The implications of a Cree response to crime. Indigenous Policy Journal, 23(1), 1-16. Retrieved from http://www.indigenouspolicy.org/index.php/ipj/article/view/47 
Hansen, J. G. (2013). Swampy Cree justice: Researching the ways of the people (2nd ed.). Vernon, BC: JCharlton.

Hansen, J. G. (2015a). Decolonizing Indigenous histories and justice. In M. Neuburger \& H. P. Dörrenbächer (Eds.), On the trail of rebirth: Nationalism and identity among the Native Americans: Case studies from North America (pp. 15-30). New York, NY: Peter Lang.

Hansen, J. (2015b). Indigenous-settler incarceration disparities in Canada: How tribal justice programming helps urban Indigenous youth. Indigenous Policy Journal, 25(3), 1-16. Retrieved from http://www.indigenouspolicy.org/index.php/ipj/article/view/290/281

Hansen, J. G., \& Antsanen, R. (2012). The pedagogy of Indigenous restorative justice. The Quint, 5(1), 29-40.

Hansen, J. G., \& Antsanen, R. (2016). Elders' teachings about resilience and its implications for education in Dene and Cree communities. The International Indigenous Policy Journal, 7(1), Art. 2. doi:10.18584/iipj.2016.7.1.2

Hansen, J. G., \& Antsanen, R. (2017). Elders teachings: Wisdom we need for addressing social exclusion and building better relationships in society. Indigenous Policy Journal, 28(21), 1-18. Retrieved from http://www.indigenouspolicy.org/index.php/ipj/article/view/410

Hansen, J. G., Booker, T. A., \& Charlton, J. E. (2014). Walking with indigenous philosophy: Justice and addictions recovery (2nd ed.). Vernon, BC: JCharlton.

Hansen, J. G., \& Hetzel, C. C. (2018). Exploring the addiction recovery experiences of urban Indigenous youth and non-Indigenous youth who utilize the services of the Saskatoon Community Arts Program. Aboriginal Policy Studies, 7(1), 84-102. doi:10.5663/aps.v7i1.28525

Hart, M. (2002). Seeking Mino-Pimatisiwin: An Aboriginal approach to helping. Halifax, NS: Fernwood.

Radu, I., House, L., \& Pashagumskum, E. (2014). Land, life, and knowledge in Chisasibi: Intergenerational healing in the bush. Decolonization: Indigeneity, Education \& Society, 3(3), 86-105. Retrieved from https://jps.library.utoronto.ca/index.php/des/article/view/21219

Smith, L. (1999). Decolonizing methodologies: Research and Indigenous peoples. New York, NY: New Zed.

Stake, R. E. (1995). The art of case study research. Newbury Park, CA: Sage.

Statistics Canada. (2016). Census profile, 2016 census: Opaskwayak Cree Nation 21A, Indian reserve [Census subdivision], Manitoba and The Pas [Population centre], Manitoba. Retrieved from http://tiny.cc/t1smyy

Truth and Reconciliation Commission of Canada. (2015). Honouring the truth, reconciling for the future: Summary of the final report of the Truth and Reconciliation Commission of Canada. Retrieved from http://www.trc.ca/websites/trcinstitution/File/2015/Findings/Exec_Summary_2015_05_3 1_web_o.pdf

Wildcat, M., McDonald, M., Irlbacher-Fox, S., \& Coulthard, G. (2014). Learning from the land: Indigenous land based pedagogy and decolonization. Decolonization: Indigeneity, Education \& Society, 3(3), 1-15. Retrieved from https://nycstandswithstandingrock.files.wordpress.com/2016/10/wildcat-et-al-2014.pdf 
Woods, P. (1996). Researching the art of teaching: Ethnography for educational use. New York, NY: Routledge.

Wotherspoon, T., \& Hansen, J. (2013). The "Idle No More" movement: Paradoxes of First Nations inclusion in the Canadian context. Social Inclusion, 1(1), 21-36. doi:10.17645/si.v1i1.107 